\title{
WOMEN FEEL MORE PESSIMISTIC THAN MEN: EMPIRICAL EVIDENCE FROM TURKISH CONSUMER CONFIDENCE INDEX
}

\author{
Aslı Küçükaslan', Sadullah Çelik² \\ ${ }^{1}$ Marmara University, FEAS, Department of Business Administration, \\ Göztepe Campus, Kadıköy, Istanbul, 34722, Turkey \\ ${ }^{2}$ Marmara University, FEAS, Department of Economics, \\ Göztepe Campus, Kadıköy, İstanbul, 34722, Turkey \\ E-mail:1'aekmekci@marmara.edu.tr, ${ }^{2}$ scelik@marmara.edu.tr
}

Received 3 February 2009; accepted 20 January 2010

\begin{abstract}
The leading role that is attributable to economic indicators like consumer confidence has been well documented in the literature for many developed nations. Moreover, the relationship between high frequency financial market data has been a common research topic for world economies. However, there is hardly any study that attempts to search for the possible functional relationship between consumer confidence and financial market variables. This paper is a simple attempt to link these two brands of literature by focusing on the relationship between financial market variables and consumer confidence index before the global crisis has started. We have two distinctive points. First, we derive separate consumer confidence indices for men and women by employing micro-level consumer confidence data from an emerging market (Turkish CNBC-e consumer confidence index) for the period of January 2003 - January 2008. Second, employing this data set, we do not only check for the existence of a relationship between consumer confidence and financial market variables (such as interest rates, exchange rates and stock exchange index) but also focus on the possibility of gender response. We find evidence of gender response difference as throughout the period women are more pessimistic than men-due probably to lower levels of wealth-and respond less to changes in exchange rates than men-due probably to lower purchasing power.
\end{abstract}

Keywords: consumer confidence; emerging market; financial market variables; gender response; co-integration.

Reference to this paper should be made as follows: Küçükaslan, A.; Çelik, S. 2010. Women feel more pessimistic than men: empirical evidence from Turkish consumer confidence index, Journal of Business Economics and Management 11(1): 146-171.

\footnotetext{
${ }^{1}$ Corresponding Author. An earlier version of this paper has been presented at the Annual Conference of the International Association for Feminist Economics held in Boston, MA, USA on 26-28 June, 2009.

2 The authors would like to acknowledge research grant provided by Marmara University Scientific Research Projects Unit under SOS-D-300409-0129.
} 


\section{Introduction}

Consumer confidence surveys try to extract information from responding agents on past, present and future economic conditions through categorical questions. In this respect, these indices have been one of the most widely used leading indicators of economic growth in many developed countries. Among them, the oldest one is University of Michigan Consumer Confidence Index which has been released regularly in the USA for the last sixty years. Recently, many emerging countries also realized the importance of leading economic indicators and have started the calculation and public announcement of such indices. In addition, the recent global financial crisis has underlined the leading role that is an inherent characteristic of economic indicators like consumer confidence. In many economies with different levels of development the responses of consumer confidence survey participants on economic outlook has been remarkably similar. This trend was even observable before the start of the global financial crisis in the post-2001 era.

On the other hand, the response of (especially emerging) financial markets to the ongoing crisis have also brought forward the need to examine the information content of financial market variables. In this mindset, one can argue that it has also become interesting to assess whether consumer confidence and financial market variables follow similar patterns during this shaky global environment.

However, this nicely built theoretical structure with the power of its elegant methodological tools has relied on conventional economic analysis lacking a fundamental part of natural order: the gender effect ${ }^{3}$. This paper is a simple attempt to bridge these two strands of literature by adding the possibility of a gender effect. Hence, we analyze the relationship between financial market variables and consumer confidence index not only by checking for the existence of a relationship but also focusing on the possibility of gender response difference. Our originality is furnished by using an emerging market, namely Turkey, in our empirical analysis. We focus on the period before the crisis started as we would like to observe whether there is any sort of relationship in a booming world economy.

The second section will include a short survey of the literature that serves as our motivation. In section three, we briefly describe the methodology and criteria for the Turkish consumer confidence index, namely the CNBC-e consumer confidence index. In section four, the methodology of our study will be introduced and the results of our empirical analysis will be presented. In conclusion, there will be a short assessment of our results and a few thoughts in this rather infant area which is a combination of psychological economics, financial economics, applied economics and feminist economics.

\section{Literature Survey}

The literature on consumer sentiment dates back to 1960s (Katona 1960,1968). The main concern of many studies has been to validate the leading indicator characteristics of consumer sentiment as well as strengthening the link between expectations and

${ }^{3}$ In a recent paper, Güneş and Çelik (2009) consider the relationship between consumer confidence and financial market variables. 
related economic variables like consumer expenditures and economic growth. Following Katona, we can cite Mishkin (1978), Throop (1991), Fuhrer (1993), Carroll et al. (1994), Nahuis (2000), Howrey (2001) and Ludvigson (2004) as some of the examples of this literature. The common finding of these studies is to show that there is some kind of a significant relationship between consumer confidence and consumption expenditures. Naturally, this finding is linked to economic growth through the important share of consumer expenditures in total output of an economy. Therefore, the theoretical framework builds on the idea that early understanding of trends in aggregate demand or business cycles provide valuable information both for policy makers and economic agents. Hence, consumer confidence has predictive ability (or extra information) for economic outlook. This proposition has been justified not only for developed countries but also for emerging markets at this stage of globalization.

However, some other studies have included different economic and financial variables in their analysis. For example, Huth et al. (1994) find that stock exchange indices of Dow Jones 30 and Standard and Poor's 500 and US consumer price index cause consumer confidence index. In a recent article, Jansen and Nahuis (2003) examine the relationship between stock exchange and consumer confidence for 11 European countries during 1986-2001. They obtain a strong positive correlation between stock returns and changes in consumer confidence and show that stock returns cause consumer confidence at very short horizons of 2 weeks to 1 month $^{4}$.

Besides these favorable studies, there are also some studies which have criticized the leading role that is attributed to consumer confidence index. Among others, Souleles (2001) offers an alternative analysis for testing the rationality of consumer expectations and evaluating their usefulness in forecasting expenditures by micro-level data. His results show that expectations seem to be biased as forecast errors by individuals do not average out even over a sample period of 20 years. Dominitz and Manski (2004) are critical about the methodology of confidence indices and propose addition of more specific questions. They believe that ordinary people cannot correctly predict the general economic conditions. Hence, survey respondents cannot provide any extra information. Likewise, Van Oest and Franses (2008) offer an alternative view for the interpretation of movements in consumer confidence and propose an applicable methodology when assessing the information content of consumer confidence.

On the other hand, there is a vast literature analyzing the relationship between probably the most widely used three variables in economic analysis, namely interest rates, stock exchange and exchange rates. The theoretical foundations for these studies can be classified in three categories as the goods market approach (flow oriented models), portfolio balance approach (stock oriented models) and omitted variable bias.

The goods market approach builds on the proposition that exchange rate changes affect the international competitiveness of an open economy and thus the profitability of its firms (Dornbusch and Fischer 1980). Therefore, exchange rate fluctuations could affect

4 Jarrett and Schilling (2008) show that it is possible to predict changes in the returns to a stratified random sample of German firms listed on the stock exchange of Frankfurt as they exhibit unit roots. 
share prices as positive or negative depending on whether the firms are net exporters/ importers, own foreign subsidiaries and hedge against exchange rate fluctuations. The portfolio balance approach argues that rising stock market ${ }^{5}$ would mean more capital inflows leading to increases in the demand for and appreciation of the home currency (Dornbusch 1975 and Frenkel 1976). Moreover, relatively higher interest rates could attract foreign capital and depress share prices. Finally, the omitted variable bias argument advocates the need to consider share prices, exchange rates and interest rates together to prevent variable misspecification due to complex interactions between financial markets due to financial globalization (Phylaktis and Ravazzolo 2005).

There are many studies which empirically analyze the bilateral relationship between the three variables. Some examples of the exchange rates-interest rates relationship include Campbell and Clarida (1987), Rogoff and Meese (1988) and MacDonald and Nagayasu (2000). Some of the studies which consider the relationship between exchange rates and stock exchange are Solnik (1987), Muhammad and Rasheed (2003) and Stavarek (2004). Among others, some of the articles which examine interest rates and stock exchange relationship are Thornton (1993) and Bernanke and Kuttner (2005). The relationship between the three variables has been investigated recently by studies like Kim (2003), Obben et al. (2006) and Çelik and Deniz (2008).

The final brand of literature that has motivated our study depends on one of the main themes of feminist economics: the gender response difference ${ }^{6}$. There have been a variety of studies questioning the importance of gender differences on several questions of interest. Among many others, one of these is the analysis of optimism vs. pessimism between genders using different instrumental scales (Dember et al. 1989 and Scheier et al. 2001). Another important concept covered by many studies focused on the possibility of gender difference in health related issues employing alternative data sets (Schraedley et al. 1999; Goldstein 2006). Furthermore, some articles have gone as far as examining the importance of gender difference in investing (Powell and Ansic 1997; Schubert et al. 1999; Charness and Gneezy 2007). However, except a few, studies in this literature have used cross section data sets ignoring the dynamic aspect of expectations. Moreover, there are hardly any studies which relate psychological aspects of decision making with economic variables on a gender based analysis.

In this mindset, the question of whether there is any difference between genders in terms of their responses to consumer confidence questions becomes our main point of interest. As consumer confidence surveys try to retrieve information content that is vital for economic outlook from economic agents, they serve several purposes by categorizing respondents in gender, age, location and other characteristics. Optimism is measured through a base scale (Usually 100) and it is easier to measure whether a gender is more optimistic or pessimistic than the other. Moreover, consumer confidence surveys pos-

\footnotetext{
${ }^{5}$ Girdzijauskas et al. (2009) argue that rising stock market could lead to bubbles that are related to inflation and therefore the factors causing inflation could also be the same factors that cause bubbles.

${ }^{6}$ Dagyte (2008) shows the existence of main management problems in gender relations using the experience of the Lithuanian women scientists within the period of 1990-2005.
} 
sess a time dimension as they are carried overtime in a certain interval. Differences in gender responses in different intervals could signal changes in patterns of behavior among genders.

For our purposes, previous studies somehow show the relation between consumer confidence, domestic demand and different variables of interest. Consumer confidence as measured by any index is an early announced and relatively inexpensive measure that operates as a proxy for consumer spending. However, it is vital to assess the specific characteristics of consumer sentiment by employing micro-level consumer survey data. This could probably help us to answer questions like whether there is a gender difference in terms of optimism/pessimism depending on economic and financial variables of interest over a certain period of time. The results will only be enhanced if this analysis uses an emerging market, namely Turkey, as our study does.

\section{Consumer Confidence Indices in Turkey}

In Turkey, there are two well-known consumer confidence indices that are announced on a monthly basis. One is the CNBC-e Consumer Confidence Index and the other one is the CBRT-TURKSTAT Consumer Confidence Index (Turkish Statistical Institute 2008). For our purposes, we employ the CNBC-e consumer confidence index as the microlevel data has been provided by the survey announcer, the CNBC-e television channel.

The methodology for the CNBC-e consumer confidence index (CCI) has been adopted from the Michigan University index of consumer sentiment with necessary changes made for Turkish households ${ }^{7}$. The base period of CCI is set as January 2002 and the value of the index at this period is 100 . The index has a point of scale ranging from 0 to 200. The sample used to collect survey data is chosen from a database maintained by the survey provider. The database contains records of 15,000,000 individuals. The index is compiled of 704 completed surveys. The survey data is obtained from the respondents between the $27^{\text {th }}$ day of the previous month and the $26^{\text {th }}$ day of the current month. The distribution of the completed surveys meets seven criteria as:

1) 70 percent is selected from Istanbul, Ankara and Izmir, 30 percent selected from other cities and big districts in Turkey.

2) 60 percent is selected from 36-55 age group, 40 percent 18-35 age group.

3) 50 percent is male and 50 percent is female.

4) 50 percent of the total surveys are composed of new records.

5) A minimum of 30 percent of new records belongs to individuals who had been successfully surveyed in the previous month.

6) A maximum 20 percent of 704 completed surveys may be composed of additional respondents and these respondents are not called again in the next month.

${ }^{7}$ Consumer confidence in the Unites States has been measured nationally by two sources. The University of Michigan produces an index of consumer sentiment based on a telephone survey of 500 households. This survey has been conducted since the 1940s and became a monthly survey in 1978 . The other, provided by the Conference Board, is a consumer confidence index that started in 1967 and became monthly in 1977. The Conference Board's index is based on a mail-out survey where approximately 2,500 responses are tabulated as they come in for a given month. 
7) Last and one of the most important criteria is that respondents are not surveyed more than two times. This helps to minimize the biases in the answers of survey respondents.

The index is composed of the questions below:

1) We would like to learn your current economic situation. Can you compare your (and your family's) current financial situation with last year?
Answer Choices: Better
Worse
Same
No Idea

2) What do you think your (and your family's) future financial situation will be in a year?

Answer Choices: Better Worse Same No Idea

3) Can you compare your current expectations about Turkish economy with the previous month?

Answer Choices: Better Worse Same Idea

4) What do you think Turkish economy's situation will be in a year?

Answer Choices: Better Worse Same No Idea

5) Do you think that the current period is a good time to buy durable consumer goods such as a TV set, a refrigerator and furniture or vehicles or residence?

Answer Choices: Good Time Bad Time No Idea

After the answers for all the surveys are compiled, CCI is calculated according to following formula:

$$
\text { Index Value }=(\text { Current period value / Base period value }) * 100 \text {. }
$$

Current period's value for each question is being calculated as $=$ ((Number of optimistic answers for the question -

Number of pessimistic answers for the question) / 704)*100) +100 .

The current period values of each question are summed up to obtain current period's value for the overall CCI. The index values for each question are announced by CNBCe as well as the announcement of sub-indices of consumer expectations index (which includes questions 2 and 4) and propensity to consumer index (which is made up of only question 5).

\section{Methodology of the Study}

This section is composed of two parts. In the first part, there is a short summary which explains the methodology of the analysis. In the second part, we present our empirical findings with short interpretations.

\subsection{Unit Roots, Cointegration and Vector Error Correction Model (VECM)}

The first part includes a brief summary of the three important empirical tools that are used for our analysis. As this is one of the first attempts to bridge the gap between different parts of economic analysis, we restrict ourselves to minimum requirements for the sake of simplicity. 


\subsubsection{Unit Roots}

Since it became a necessity for economic theory to have the support of empirical findings, there have been remarkable developments in the area of econometrics. But none had the impact of unit root tests and the following literature. It is well known that the need to test the existence of unit roots depends on the inherent characteristics of economic variables. Real world data shows that it is a matter of time whether an economic variable reverts back to some long-run mean following a shock or exhibits random walk behavior. Hence, a random walk process without drift is written as

$$
x_{t}=x_{t-1}+u_{t},
$$

with $E\left(u_{t}\right)=0, E\left(u_{t} u_{s}\right)=0$ for, $t \neq s$ and $E\left(u_{t} u_{s}\right)=\sigma^{2}$ for $t=s$. Therefore, a random walk is a special case of the autoregressive process (AR), $x_{t}=\alpha_{0}+\alpha_{1} x_{t-1}+u_{t}$, where $\alpha_{0}=0$ and $\alpha_{1}=1$. A time series with no deterministic component which has a stationary, invertible, autoregressive moving average (ARMA) representation after differencing $\mathrm{d}$ times is said to be integrated of order $\mathrm{d}$, denoted $x_{t} \sim \mathrm{I}(\mathrm{d})$. Thus, for $d=0, x_{t}$ will be stationary (and $x_{t}$ has no unit root) and for $d=1$, the change in $x_{t}$ is stationary (and $x_{t}$ has a unit root).

The common procedure in economics is to test for the presence of a unit root to detect non-stationary behavior in a time series. There are several unit root tests like the Dickey-Fuller test (ADF) (Dickey and Fuller 1979, 1981; Said and Dickey 1984), and the Kwiatkowski et al. (1992) test (KPSS). This study uses both ADF and KPSS tests so that there is no a priori belief on the behavior of the time series.

\subsubsection{Cointegration}

Granger (1981) has laid the foundations for the concept of cointegration and the theoretical part was more fully developed in Engle and Granger (1987). The cointegration of two variables is at least a necessary condition for them to have a stable long-run (linear) relationship. Johansen (1988) and Johansen and Juselius (1990) proposed a procedure for estimating cointegrating relationships in a system of equations framework. This method allows for the testing of more than one cointegrating vector in the data and for the calculation of maximum-likelihood estimates of these vectors. The JohansenJuselius (JJ) methodology employs a statistical model of the following form:

$$
\Delta X_{t}=\Gamma_{1} \Delta X_{t-1}+\ldots+\Gamma_{k-1} \Delta X_{t-k+1}+\Pi X_{t-k}+\mu+\Psi D_{t}+\varepsilon_{t},
$$

where $\Gamma_{i}=-\left(I-\Pi_{1}-\ldots-\Pi_{i}\right)$ and $\Pi=-\left(I-\Pi_{1}-\ldots-\Pi_{k}\right)$.

The JJ technique decomposes the matrix $\Pi(p x p)$ to find information about the longrun relationships between the variables in $X_{t}$. In particular, if $\Pi$ has a rank of $\mathrm{r}$ where $0<r<p$, then we can show that $\Pi=\alpha \beta^{\prime}$ where $\beta^{\prime}$ is an (rxp) matrix of $\mathrm{r}$ cointegrating vectors (so that the $\mathrm{r}$ linear combinations, $\beta_{i}{ }^{\prime} X_{t}$, are stationary) and $\alpha$ is $a(p x r)$ matrix of adjustment speeds. Thus, the hypothesis of at most $\mathrm{r}$ cointegrating vectors is formulated as the restriction $H_{0}: \Pi=\alpha \beta^{\prime}$ where $\operatorname{rank}(\Pi)=r$. Equation (4) can be simplified as 


$$
Z_{0 t}=\Phi Z_{1 t}+\prod Z_{k t}+\varepsilon_{t}
$$

where $Z_{0 t}=\Delta X_{t}, Z_{1 t}$ denotes the stacked variables $\Delta X_{t-1}, \ldots . ., \Delta X_{t-k+1}, \mathrm{D}_{\mathrm{t}}$ and $1, Z_{k t}=$ $X_{t-k}$, and $\Phi$ is the matrix of parameters corresponding to $Z_{1 \mathrm{t}}$. JJ define several product moment matrices as

$$
\stackrel{T}{M}=T^{-1} \sum Z_{i t} Z_{j t} \text { with } i, j=0,1, k
$$

These matrices are combined to form

$$
S_{i j}=M_{i j}-M_{i 1} M_{11}^{-1}-M_{i j} \text { with } i, j=0, \ldots ., k .
$$

Under the null hypothesis of $H_{0}: \Pi=\alpha \beta^{\prime}$, the maximum likelihood estimator of $\beta$ is the set of eigenvectors associated with the eigenvalues $(\lambda)$ solved from the following equation:

$$
\left|\lambda S_{k k}-S_{k 0} S_{00}^{-1} S_{0 k}\right|=0 .
$$

To determine the value of $r$, Johansen (1988) constructed two likelihood ratio (LR) statistics. One statistic is called the maximal eigenvalue test $(\lambda-\max )$ and compares the null of $H_{0}(r)$ with an alternative of $H_{1}(r+1)$. It is calculated as

$$
\lambda-\max _{\wedge}(r)=-T \ln \left(1+\hat{\lambda}_{r+1}\right),
$$

where $\lambda_{r+1}$ is the $(r+1)$ largest estimated eigenvalue. The second statistic, i.e., trace statistic, tests a sequence of null hypotheses $r=0, r \leq 1, \ldots, r \leq p-1$, and is calculated as

$$
\underset{\wedge}{\operatorname{Trace}}(r)=-T \sum_{i=r+1}^{p}\left(1-\hat{\lambda}_{i}\right),
$$

where $\lambda_{i}$ are the $(p-r-1)$ smallest estimated eigenvalues and $\mathrm{p}$ is the number of variables. We use only the trace test in our empirical analysis as it has powerful properties compared to the maximal eigenvalue test.

\subsubsection{VECM}

As Granger (1981) and Engle and Granger (1987) demonstrate, the existence of cointegration removes the possibility of the estimated regression being spurious due to problems such as omitted variable bias, autocorrelation and endogeneity. The direction of causality among the cointegrated variables could be solved by using the vector error correction models.

The VECM augments a vector autoregressive process in first differences of the variables with their cointegrating relationship. In this sense, it has several attractive characteristics. First, the structure of the VECM explicitly designates a role for the difference between the consumer confidence and financial market variables used in this study. Ceteris paribus, if the error-correction term equaled zero, there would be no need for either consumer confidence or any financial market variable(s) to adjust from its (their) current level(s). Second, the estimation of the error-correction term leads to a direct examination into the behavior of the gap between consumer confidence and financial market variables over the data span. Finally, it is possible to examine the sign and 
magnitude of the error correction coefficients and analyze the characteristics of the adjustment process by which long-run equilibrium between the series is restored. This means that VECM helps us to understand the dynamics of the short run relationship between the variables of interest.

We can write a typical four-variable VECM for the consumer confidence index $(C C I)$, stock exchange index $(S E)$, exchange rate variable $(E X C)$, and interest rate variable (INT) as follows:

$$
\begin{aligned}
& \Delta C C I_{t}=\alpha_{1}+\sum^{j} \beta_{1}(i) \Delta C C I_{t-i}+\sum^{j} \delta_{1}(i) \Delta S E_{t-i}+ \\
& \sum^{j} \zeta_{1}(i) \Delta I N T_{t-i}+\sum^{j} \theta_{1}(i) \Delta E X C_{t-1}^{a}+\lambda_{1} E C T_{t-1}+\varepsilon_{1 t} ; \\
& \Delta S E_{t}=\alpha_{2}+\sum^{k} \beta_{2}(i) \Delta C C I_{t-i}+\sum^{k} \delta_{2}(i) \Delta S E_{t-i}+ \\
& \sum^{k} \zeta_{2}(i) \Delta I N T_{t-i}+\sum^{k} \theta_{2}(i) \Delta E X C_{t-i}^{a}+\lambda_{2} E C T_{t-1}+\varepsilon_{2 t} ; \\
& \Delta E X C_{t}^{a}=\alpha_{3}+\sum^{l} \beta_{3}(i) \Delta C C I_{t-i}+\sum^{l} \delta_{3}(i) \Delta S E_{t-i}+ \\
& \sum^{l} \zeta_{3}(i) \Delta I N T_{t-i}+\sum^{l} \theta_{3}(i) \Delta E X C_{t-i}^{a}+\lambda_{3} E C T_{t-1}+\varepsilon_{3 t} ; \\
& \Delta I N T_{t}=\alpha_{4}+\sum^{m} \beta_{4}(i) \Delta C C I_{t-i}+\sum^{m} \delta_{4}(i) \Delta S E_{t-i}+ \\
& \sum^{m} \zeta_{4}(i) \Delta I N T_{t-i}+\sum^{m} \theta_{4}(i) \Delta E X C_{t-i}^{a}+\lambda_{4} E C T_{t-1}+\varepsilon_{4 t},
\end{aligned}
$$

where $\Delta$ shows the first-difference operator, ECT denotes the error correction term, the terms $\mathrm{j}, \mathrm{k}, 1$ and $\mathrm{m}$ stand for the lag lengths determined according to the Akaike Information Criteria, and a is for alternative specifications of the variable. The coefficients of $E C T_{t-1}, \lambda_{1}, \lambda_{2}, \lambda_{3}$, and, $\lambda_{4}$ show the adjustments of $\Delta C C I_{t}, \Delta S E_{t}, \Delta E X C_{t}$, and $\Delta I N T_{t}$ towards long-run equilibrium.

\subsection{Empirical Findings}

The empirical analysis starts with the conventional unit root tests, followed by cointegration analysis and the normalized coefficient estimates from cointegration, and finally the VECM analysis.

The study employs a four-variable setup while searching for the long-run relationship between consumer confidence, stock exchange index, exchange rate and interest rate. The consumer confidence variable (CCI) is the CNBC-e consumer confidence index, for the stock exchange index, we use the Istanbul Stock Exchange 100 Index (ISE100). There are two alternative variables employed for the exchange rate as the average of $(1 \$+1 €)$ exchange rate (BASKET), and only the dollar exchange rate (DOLLAR). Finally, the interest rate variable is the simple annual interest rate (INTSIM) for the bond/bill with the highest volume in the bond market for the corresponding period. The data span is $1^{\text {st }}$ January $2003-23^{\text {rd }}$ January $2008^{8}$. All variables except INTSIM are in their natural logarithms.

\footnotetext{
${ }^{8}$ The original computerized daily data for CCI starts in July 2002. However, there is a highly volatile economic and political environment in Turkey during July-December 2002. Hence, we prefer to start our empirical analysis at the beginning of the year 2003 .
} 
The CCI is calculated ${ }^{9}$ using the data obtained from CNBC-e/NTV Consumer Confidence Index Survey Provider (NTVMSNBC 2008). A quick glance at the plot of CCI for men and CCI for women demonstrate that women are more pessimistic than men throughout the period of analysis. Figure 1 in Appendix shows that the pink line hardly stays over the blue line, clearly a sign of economic impotence for women in an emerging market where jobs are hard to get and female labor force participation goes down over time. ISE100 is obtained from ISE website (Istanbul Stock Exchange 2008), DOLLAR and EURO exchange rates are obtained from CBRT website (Central Bank of Republic of Turkey 2008) and INTSIM is obtained also by using the ISE website (Istanbul Stock Exchange 2008).

\subsubsection{Unit Root Test Results}

Table 1 in Appendix shows the ADF unit root tests for levels and differences including only an intercept and both an intercept and a trend. The results for all the variables in levels are similar as we are unable to reject the null of unit root at $5 \%$ significance level except for BASKET and INTSIM in case of a drift and CCI_WOMEN in case of a drift and a trend. Moreover, the results for all the variables in differences are identical as we reject the null of unit root at 5\% significance level regardless of the case considered. On the other hand, the KPSS test results are in Table 2 in Appendix. The only variables in levels which seem stationary are BASKET in both cases of a constant and a constant and a trend and DOLLAR in case of a constant and a trend. This signals that we should be careful in dealing with BASKET in our equations as we get no unit root for 3 cases out of 4. Nevertheless, it appears that all our variables except the BASKET could be classified as non-stationary, having a unit root.

\subsubsection{Cointegration Test Results}

Once we detect the presence of unit root, we move on to check whether our I(1) series are cointegrated. The results of Johansen-Juselius trace cointegration test statistics are shown in Table 3 in Appendix for men and Table 4 in Appendix for women employing the cases of a constant and a constant and a trend. Different combinations of variables show the existence of a cointegrating vector for 7 cases when CCI for men is used and for 11 cases when CCI for women is used. Hence, we could argue that there is a longrun co-movement between the variables of interest, regardless of a gender difference.

Therefore, it becomes important to analyze the coefficient estimates of the cointegration relationship to derive inferences about the long-run relationship. The normalized cointegrating coefficients from Johansen-Juselius estimation are in Table 5 in Appendix for men and Table 6 in Appendix for women. Here, we deal with not only the significance

\footnotetext{
${ }^{9}$ The CCI values are calculated daily with reference to the starting base value of January 2002. The daily values for the starting days of the new survey for each month (Between $26^{\text {th }}$ and the end of the previous month) is set equal to the announced value of the previous month so that a large number of survey responses will be gathered that can be used to calculate the new month's daily values when the new month actually starts on the $1^{\text {st }}$. The daily averages constitute the weekly data that we use. We also check for serial correlation and reject the null of serial correlation for all our series. The results are not reported here to save space and available from the authors upon request.
} 
of the coefficient estimates but also their size and magnitude. We could summarize the results as follows:

a) The coefficient estimates for the stock exchange show drastic difference between men and women in Turkey ${ }^{10}$. Male CCI survey respondents end up with a positive and mostly significant coefficient for stock exchange index. This is in accordance with the theoretical framework that an increase in stock exchange leads to an increase in consumer sentiment due to expectations of future economic growth. However, the picture is reversed for female CCI respondents. We observe mostly insignificant and negative coefficients.

During the period 2003-2007, the share of foreign investors in Istanbul Stock Exchange has increased significantly. It is rather interesting to observe that this development has affected the attitude of women rather than men. In this sense, the adverse reaction of private female households to a rise in the stock exchange index shows the sensitivity of women.

b) Considering the alternative definitions of the exchange rate, we observe negative and statistically significant coefficients for men. This is in line with our a priori expectations and leads us to believe that male households in Turkey lose confidence as the purchasing power declines. On the other hand, there is a mixed response from the female side. We obtain 4 positive and significant coefficients as well as 1 negative and significant coefficient. Nevertheless, the dominance of positive and significant coefficients depicts the lower levels of wealth in terms of domestic currency for Turkish female households. Moreover, it is a clear sign for the lack of motivation to participate in labor force. The income and wealth level of female survey respondents hardly suffers when domestic purchasing power declines.

c) The last variable we include in our analysis is the interest rate and the empirical findings for men and women are rather surprisingly very similar. Moreover, the coefficients are all significant and positive in magnitude. This clearly is against the theoretical framework and leads us to believe that the interest rate measure used here is probably not the one that the households observe every day. However, given the high levels of correlation between all interest rates, it is reasonable to argue that survey respondents should have some sense of the prevailing interest rate in the market. Nonetheless, this is not the result for our study, probably due to lower levels of bond holding by households.

\subsubsection{VECM Results}

Table 7 and Table 8 in Appendix report the results from estimation of the VECM in equations 11,12,13, and 14 with the choice of lag length for the first differences of the series again determined using the AIC. The error-correction term is statistically significant in each equation for CCI and the coefficients for the error-correction term are of the opposite sign, supporting the adjustment process for each series. Specifically, a value of CCI above (below) its long-run equilibrium in one period will produce upward (downward) pressure on the variables in the subsequent period.

${ }^{10}$ Teresienè (2009) argues that investor's psychology acts as the factor that causes price volatility in stock markets. 


\section{Conclusion}

Many studies have examined the relationship between consumer confidence indices and economic growth. They have focused on the forecasting ability of consumer confidence indices believing that it contains information content which most of the other variables lack. However, there has been no general consensus on whether consumer confidence indices can be used as congruent indicators of economic activity. The main flaw of this literature has been the improper micro-level analysis of the data set at hand.

This study is an attempt to enhance the consumer confidence literature by shifting the focus from the information content of consumer confidence to the criteria content of consumer confidence. Among others, the foremost criterion for any consumer confidence index is the equal number of respondents from the two genders. Hence, we choose to examine whether there is a gender difference in consumer confidence data. Moreover, this is done for an emerging economy, Turkey.

Turkey is a dynamic developing country, and we believe that it serves our purpose well as our empirical analysis demonstrates gender response difference. Over the recent period of 2003-2007, women feel more pessimistic than men in Turkey. This can be attributed to several reasons. First and foremost, women lack purchasing power and hence they can hardly make any decisions on the future of themselves (and their family). Second, women hardly hold any wealth which could be channeled into assets that will generate a prosperous future for them. Finally, women respond rather different than men to changes in financial market variables. This is related to low levels of foreign exchange and stock holdings by women.

Consequently, our study shows that there is a difference between the attitudes of women and men in Turkey. This is important as it emphasizes the lack of necessary precautions by authorities to bring women into the labor force. Any developing country should build its future sustainable growth pattern on a strong labor force which forms the middle class. Without women, this middle class can hardly survive rather than help the economy develop. Hence, this study shows that women should be given a major role in the development process of a nation. This role needs to be as important as the role of men. Otherwise, a developing country will continue to be a middle to low income country for a long period of time.

\section{References}

Bernanke, B. S.; Kuttner, K. N. 2005. What explains the stock market's reaction to Federal Reserve policy? Journal of Finance, American Finance Association 60(3): 1221-1257.

Campbell, J. Y.; Clarida, R. H. 1987. The dollar and real interest rates, Carnegie-Rochester Conference Series on Public Policy 27: 103-139. doi:10.1016/0167-2231(87)90005-4

Carroll, C. D.; Fuhrer, J. C.; Wilcox, D.W. 1994. Does Consumer sentiment forecast household spending? If so, why? American Economic Review 84: 1397-1408.

Charness, G.; Gneezy, U. 2007. Strong evidence for gender differences in investment. Working Paper, University of California at Santa Barbara. 
Çelik, S.; Deniz, P. 2008. Panel cointegration analysis for stock exchange, exchange rates and interest rates: an application to the European Union, in Paper presented at The $15^{\text {th }}$ World Congress of the International Economic Association, June, İstanbul, Turkey.

Central Bank of Republic of Turkey (online) 2008 [cited 25 January 2008]. Available from Internet: <http://www.tcmb.gov.tr>.

Dagyte, I. 2008. Lithuanian women in science: management facets, Verslas: teorija ir praktika [Business: Theory and Practice] 9(1): 65-72. doi:10.3846/1648-0627.2008.9.65-72

Dember, W. N.; Martin, S.; Hummer, M. K.; Howe, S.; Melton, R. 1989. The Measurement of optimism and pessimism, Current Psychology: Research and Reviews 8: 102-119. doi:10.1007/BF02686675

Dickey, D. A.; Fuller, W. A. 1979. Distribution of the estimators for autoregressive time series with a unit root, Journal of the American Statistical Association 74: 427-431. doi:10.2307/2286348

Dickey, D. A.; Fuller, W. A. 1981. Likelihood ratio tests for autoregressive time series with a unit root, Econometrica 49: 1057-1072. doi:10.2307/1912517

Dominitz, J.; Manski, C. F. 2004. How should we measure consumer confidence? Journal of Economic Perspectives 18(2): 51-66. doi:10.1257/0895330041371303

Dornbusch, R. 1975. A portfolio balance model of the open economy, Journal of Monetary Economics 1(1): 3-20. doi:10.1016/0304-3932(75)90003-3

Dornbusch, R.; Fischer, S. 1980. Exchange rates and the current account, American Economic Review 70: 960-71.

Engle, R. F.; Granger, C. W. J. 1987. Co-integration and error correction: representation, estimation and testing, Econometrica 55: 251-276. doi:10.2307/1913236

Frenkel, J. 1976. A monetary approach to the exchange rate: doctrinal aspects and empirical evidence, Scandinavian Journal of Economics 78(2): 200-224. doi:10.2307/3439924

Fuhrer, J. C. 1993. What role does consumer sentiment play in the U.S. macroeconomy? New England Economic Review Jan/Feb, 32-44.

Girdzijauskas, S.; Štreimikienè, D.; Čepinskis, J.; Moskaliova, V. 2009. Formation of economic bubbles: causes and possible preventions, Technological and Economic Development of Economy 15(2): 267-280. doi:10.3846/1392-8619.2009.15.267-280

Goldstein, B. I. 2006. Why do women get depressed and men get drunk? an examination of attributional style and coping style in response to negative life events among Canadian young adults, Sex Roles 54(1/2): 27-37. doi:10.1007/s11199-006-8867-8

Granger, C. W. J. 1981. Some properties of time series data and their use in econometric model specification, Journal of Econometrics 16(1): 121-130. doi:10.1016/0304-4076(81)90079-8

Güneş, H.; Çelik, S. 2009. Consumer confidence and financial market variables in an emerging economy: The case of Turkey, Paper presented at the Society for Computational Economics $15^{\text {th }}$ International Conference on Computing in Economics and Finance, July, Sydney, Australia.

Howrey, E. P. 2001. The predictive power of the index of consumer sentiment, Brookings Papers on Economic Activity 1: 175-216. doi:10.1353/eca.2001.0010

Huth, W.; Eppright, D. R.; Taube, P. M. 1994. The indexes of consumer sentiment and confidence: leading or misleading guides to future buyer behavior, Journal of Business Research 29(3): 199-206. doi:10.1016/0148-2963(94)90004-3

Istanbul Stock Exchange (online) 2008 [cited 24 January 2008]. Available from Internet: <http:// www.imkb.gov.tr>.

Jansen, W. J.; Nahuis, N. J. 2003. The stock market and consumer confidence: European evidence, Economics Letters 79(1): 89-98. doi:10.1016/S0165-1765(02)00292-6 
Jarrett, J. E.; Schilling, J. 2008. Daily variation and predicting stock market returns for the Frankfurter Börse (stock market), Journal of Business Economics and Management 9(3): 189-198. doi:10.3846/1611-1699.2008.9.189-198

Johansen, S. 1988. Statistical analysis of cointegration vectors, Journal of Economic Dynamics and Control 12(2-3): 231-254. doi:10.1016/0165-1889(88)90041-3

Johansen, S.; Juselius, K. 1990. Maximum likelihood estimation and inference on cointegrationwith application to the demand for money, Oxford Bulletin of Economics and Statistics 52: 169-210.

Katona, G. 1960. The powerful consumer. New York: McGraw Hill.

Katona, G. 1968. Consumer behavior: theory and findings on expectations and aspirations, American Economic Review 58: 19-30.

Kim, K. 2003. Dollar exchange rate and stock price: evidence from multivariate cointegration and error correction model, Review of Financial Economics 12(3): 301-313.

doi:10.1016/S1058-3300(03)00026-0

Kwiatkowski, D.; Phillips, P. C. B.; Schmidt, P.; Shin, Y. 1992. Testing the null hypothesis of stationarity against the alternative of a unit root: how sure are we that economic time series have a unit root? Journal of Econometrics 54(1-3): 159-178. doi:10.1016/0304-4076(92)90104-Y

Ludvigson, S. C. 2004. Consumer confidence and confidence spending, Journal of Economic Perspectives 18(2): 29-50. doi:10.1257/0895330041371222

MacDonald, R.; Nagayasu, J. 2000. The long-run relationship between real exchange rates and real interest rate differentials: a panel study, IMF Staff Papers 47(1): 116-128.

Rogoff, K.; Meese, R. A. 1988. Was It Real? The exchange rate-interest differential relation over the modern floating-rate period, Journal of Finance 43(4): 933-948. doi:10.2307/2328144

Mishkin, F. S. 1978. Consumer sentiment and spending on durable goods, Brookings Papers on Economic Activity 1: 217-232. doi:10.2307/2534366

Muhammad, N.; Rasheed, A. 2003. Stock prices and exchange rates: are they related? Evidence from south Asian countries. Paper presented at the $18^{\text {th }}$ Annual General Meeting and Conference of the Pakistan Society of Development Economists, January.

Nahuis, N. J. 2000. Are Survey indicators useful for monitoring consumption growth? Evidence from European countries, Working Paper 2000-08 (June), Monetary and Economics Policy Department, De Nederlandsche Bank, Amsterdam.

NTVMSNBC (online). 2008 [cited 28 January 2008]. Available from Internet: <http://www. ntvmsnbc.com>.

Obben, J.; Pech, A.; Shakur, S. 2006. Analysis of the relationship between the share market performance and exchange rates in New Zealand: A cointegrating VAR approach, Massey University Discussion Paper, No. 06.08., 1-27. ISSN 1174-2542.

Phylaktis, K.; Ravazzolo, F. 2005. Stock prices and exchange rate dynamics, Journal of International Money and Finance 24(7): 1031-1053. doi:10.1016/j.jimonfin.2005.08.001

Powell, M.; Ansic, D. 1997. Gender differences in risk behaviour in financial decision-making: an experimental analysis, Journal of Economic Psychology 18(6): 605-628.

doi:10.1016/S0167-4870(97)00026-3

Said, S. E.; Dickey, D. A., 1984. Testing for unit roots in autoregressive moving average models of unknown order, Biometrika 71(3): 599-607. doi:10.1093/biomet/71.3.599

Scheier, M. F.; Carver, C. S.; Bridges, M. W. 2001. Optimism, pessimism, and psychological well-being, in E. C. Chang (Ed.). Optimism and Pessimism: Implications for Theory, Research, and Practice, Washington, DC: American Psychological Association, 189-216.

doi:10.1037/10385-009 
Schraedley, P. K.; Gotlib, I. H.; Hayward, C. 1999. Gender differences in correlates of depressive symptoms in adolescents, Journal of Adolescent Health 5(2): 98-108.

doi:10.1016/S1054-139X(99)00038-5

Schubert, R.; Gysler, M.; Brown, M.; Brachinger, H. 1999. Financial decision-making: are women really more risk averse? American Economic Review Papers and Proceedings 89(2): 381-385.

Solnik, B. 1987. Using financial prices to test exchange rate models: A note, Journal of Finance 42(1): 141-149. doi:10.2307/2328424

Souleles, N. S. 2001. Consumer sentiment: its rationality and usefulness in forecasting expenditure-evidence from the Michigan micro data, NBER Working Paper 8410, Cambridge, MA.

Stavarek, D. 2004. Stock prices and exchange rates in the EU and the USA: Evidence of their mutual interactions. MPRA Paper No. 7297.

Teresienè, D. 2009. Lithuanian stock market analysis using a set of GARCH models, Journal of Business Economics and Management 10(4): 349-360. doi:10.3846/1611-1699.2009.10.349-360

Thornton, J. 1993. Money, output and stock prices in the UK: Evidence on some (non)relationships, Applied Financial Economics 3(4): 335-338. doi:10.1080/758534946

Throop, A. 1991. Consumer sentiment and the economic downturn. Weekly Letter, Federal Reserve Bank of San Francisco, March.

Turkish Statistical Institute (online). 2008 [cited 31 January 2008]. Available from Internet: $<$ http://www.tuik.gov.tr>.

Van Oest, R.; Franses, P. H. 2008. Measuring changes in consumer confidence, Journal of Economic Psychology 29(3): 255-275. doi:10.1016/j.joep.2007.10.001

\title{
MOTERŲ PESIMIZMAS DIDESNIS NEI VYRŲ: EMPIRINIS PAGRINDIMAS REMIANTIS TURKIJOS PIRKĖJŲ PASITIKĖJIMO INDEKSU
}

\author{
Aslı Küçükaslan, Sadullah Çelik
}

Santrauka

Ekonominių rodiklių kaip pirkèjo pasitikejjimo vaidmens svarba yra išsamiai pagrịsta daugelio išsivysčiusių šalių literatūroje. Be to, ryšys tarp aukšto finansų rinkos svyravimo duomenų yra dažna tyrimų tema daugelyje pasaulio šalių. Tačiau vargu ar galima būtų rasti tyrimų, kuriuose būtų bandoma surasti funkcini ryši tarp pirkejjo pasitikejjimo ir finansų rinkų rodiklių. Šis straipsnis - tai mėginimas susieti šias dvi rūšis, orientuojantis i ryšị tarp finansų rinkų rodiklių ir pirkejjo pasitikejjimo indekso prieš prasidedant pasaulinei krizei. Šiame straipsnyje pabrěžti du išskirtiniai bruožai. Pirma, nustatomi atskiri moterų ir vyrų pasitikejjimo indeksai naudojantis $2003 \mathrm{~m}$. sausio mèn. - $2008 \mathrm{~m}$. sausio mèn. laikotarpio augančiu rinkų mikrolygmens pirkèjo pasitikejjimo duomenimis (Turkų CNBC-e pirkejjo pasitikèjimo indeksas). Antra, naudojantis šia informacija tikrinamas ne tik esamas ryšys tarp pirkejjo pasitikejjimo ir finansų rinkų rodiklių (pavyzdžiui, palūkanų normos, valiutų kurso, akcijų biržos indekso). Buvo rasta akivaizdžių skirtumų tarp atsakymų, gautų iš skirtingų lyčių atstovų. Visą laikotarpi moterys buvo pesimistiškesnès nei vyrai, tikriausiai dèl žemo gerovès lygio. Jos mažiau reagavo į valiutų kurso pokyčius nei vyrai dèl mažesnès perkamosios galios.

Reikšminiai žodžiai: vartotojų pasitikėjimas, augančios rinkos, finansų rinkos rodikliai, lyčių atsakymai, kointegracija. 
Aslı KÜÇÜKASLAN is an Associate Professor in the Department of Business Administration, Marmara University Faculty of Economics and Administrative Sciences, İstanbul, Turkey. She received her BA, MA and PhD in Business Administration from Marmara University Faculty of Economics and Administrative Sciences. She has authored numerous articles and a book about strategic management, global branding, business management, product positioning and mergers and acquisitions in Turkish and English. She has also coordinated a project under the authority of Marmara University on the gender response difference in consumer confidence in Turkey. Moreover, she has attended several international and national conferences presenting papers, serving as the discussant and chair. She also supervised several MA and $\mathrm{PhD}$ dissertations of students from Marmara University.

Sadullah ÇELIK is an Assistant Professor in the Department of Economics, Marmara University Faculty of Economics and Administrative Sciences, İstanbul, Turkey. He received his BA and MA in Economics from Marmara University Faculty of Economics and Administrative Sciences, İstanbul, Turkey. He received his PhD in Economics from the University of Nebraska-Lincoln, USA. He has authored numerous articles about applied economics, international economics, behavioral economics and consumer sentiment, in Turkish and English, and co-authored a book about construction industry in Turkey, in Turkish. In addition, he has coordinated a project under the authority of Marmara University on day of the week effect on consumer confidence. Furthermore, he has attended several international and national conferences presenting papers, serving as a discussant and chair and organizing invited sessions. Likewise, he has refereed numerous articles for international journals. Moreover, he has served three years as the LLP-Erasmus Coordinator for the Department of Economics, Marmara University Faculty of Economics and Administrative Sciences. He also supervised several MA theses and $\mathrm{PhD}$ dissertations of students from many universities such as İstanbul Bilgi University, İstanbul Commerce University and Marmara University. 


\section{APPENDIX}

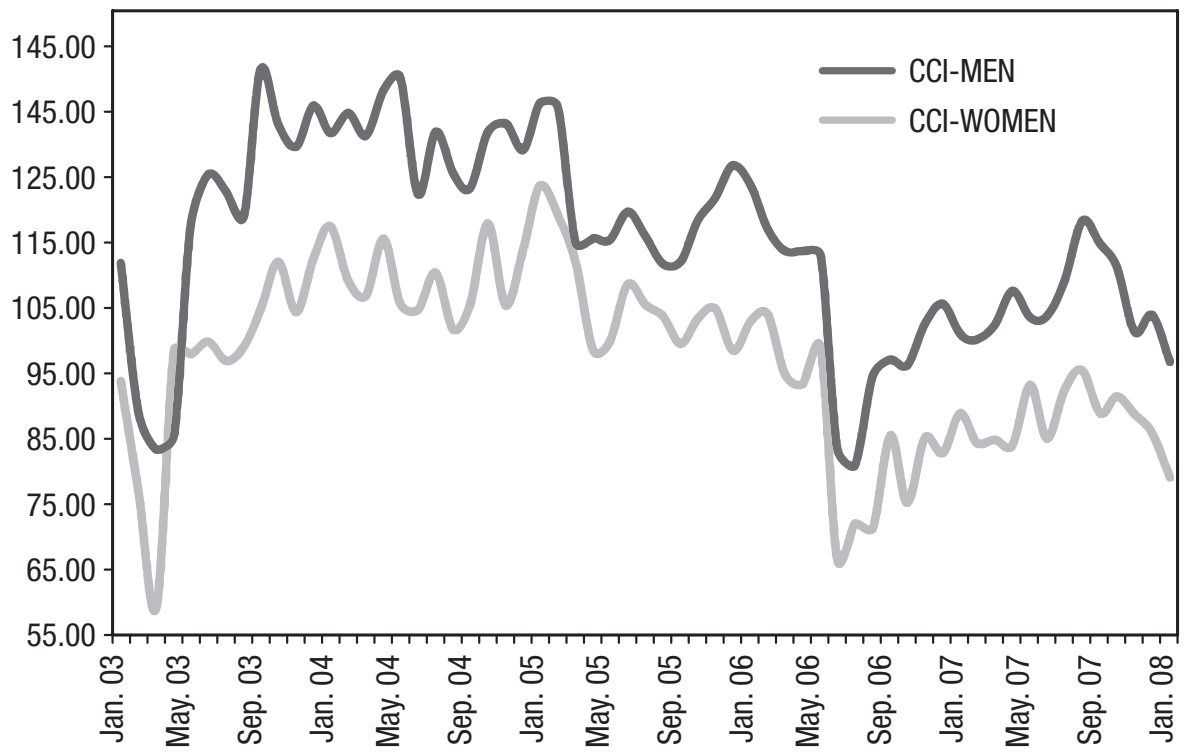

Fig. 1. CNBC-e Turkish consumer confidence index for women and men

Table 1. ADF unit root tests

\begin{tabular}{ccccc}
\hline $\begin{array}{c}\text { ADF UNIT ROOT } \\
\text { TESTS } \\
\mathbf{0 8 / 0 1 / 2 0 0 3}-\mathbf{2 3 / 0 1 / 2 0 0 8}\end{array}$ & $\begin{array}{c}\text { Level } \\
\text { with } \\
\text { constant }\end{array}$ & $\begin{array}{c}\text { Level } \\
\text { with } \\
\text { trend }\end{array}$ & $\begin{array}{c}\text { Difference } \\
\text { with } \\
\text { constant }\end{array}$ & $\begin{array}{c}\text { Difference } \\
\text { with } \\
\text { trend }\end{array}$ \\
\hline VARIABLE & ADF & ADF & ADF & ADF \\
\hline CCI_WOMEN & -2.4969 & $-3.6697^{*}$ & $-16.667^{* *}$ & ----- \\
\hline CCI_MEN & -2.6550 & -3.1287 & $-17.768^{* *}$ & $-17.745^{* *}$ \\
\hline ISE100 & -1.6631 & -1.4234 & $-8.1503^{* *}$ & $-8.2243^{* *}$ \\
\hline BASKET & $-2.8884^{*}$ & -2.9020 & ---- & $-5.8775^{* *}$ \\
\hline DOLLAR & -2.5057 & -2.8323 & $-5.9027^{* *}$ & $-5.8908^{* *}$ \\
\hline INTSIM & $-3.1746^{*}$ & -2.2602 & ----- & $-7.1117^{* *}$ \\
\hline
\end{tabular}

Notes: The critical values for the case with Constant are -3.455193 for $1 \%$ and -2.872370 for $5 \%$ significance levels and for the case with Trend are -3.993746 for $1 \%$ and -3.427203 for $5 \%$ significance levels. $(*)$ denotes significance at $5 \%$ level and $(* *)$ denotes significance at $1 \%$ level. The lag selection is done using the Modified HQ Information Criteria with the maximum lag length set to 8 .

Table 2. KPSS unit root tests

\begin{tabular}{ccccc}
\hline $\begin{array}{c}\text { KPSS UNIT ROOT } \\
\text { TESTS } \\
\mathbf{0 8 / 0 1 / 2 0 0 3}-\mathbf{2 3 / 0 1 / 2 0 0 8}\end{array}$ & $\begin{array}{c}\text { Level } \\
\text { with } \\
\text { constant }\end{array}$ & $\begin{array}{c}\text { Level } \\
\text { with } \\
\text { trend }\end{array}$ & $\begin{array}{c}\text { Difference } \\
\text { with } \\
\text { constant }\end{array}$ & $\begin{array}{c}\text { Difference } \\
\text { with } \\
\text { trend }\end{array}$ \\
\hline VARIABLE & KPSS & KPSS & KPSS & KPSS \\
\hline CCI_WOMEN & $0.8858^{* *}$ & $0.2799^{*}$ & 0.0438 & 0.0261 \\
\hline CCI_MEN & $0.7540^{* *}$ & $0.1928^{*}$ & 0.0376 & 0.0220 \\
\hline
\end{tabular}


End of Table 2

\begin{tabular}{ccccc}
\hline ISE100 & $2.0109^{* *}$ & $0.3162^{*}$ & 0.2391 & 0.0397 \\
\hline BASKET & 0.1647 & 0.0999 & ---- & ---- \\
\hline DOLLAR & $0.7115^{*}$ & 0.1365 & 0.0688 & ---- \\
\hline INTSIM & $1.2338^{* *}$ & $0.3999^{* *}$ & $0.5292^{*}$ & 0.0857 \\
\hline
\end{tabular}

Notes: The critical values for the case with Constant are 0.739 for $1 \%$ and $0.4635 \%$ significance levels, and for the case with Trend are 0.216 for $1 \%$ and 0.146 for $5 \%$ significance levels. $(*)$ denotes significance at $5 \%$ level, and $(* *)$ denotes significance at $1 \%$ level. The KPSS test is computed using the Bartlett kernel to account for the potential correlation of the residuals with a bandwidth automatically selected using the Newey-West Bandwidth.

Table 3. Johansen-Juselius cointegration tests-MEN

\begin{tabular}{|c|c|c|c|}
\hline \multicolumn{2}{|l|}{ PERIOD: 08/01/2003 - 23/01/2008 } & \multirow{2}{*}{$\frac{\text { Constant }}{\text { Trace }}$} & \multirow{2}{*}{$\begin{array}{c}\text { Trend } \\
\text { Trace }\end{array}$} \\
\hline VARIABLES & Null & & \\
\hline CCI MEN & $r=0$ & $43.82674 *$ & $47.46984 *$ \\
\hline BAS̄KET & $\mathrm{r} \leq 1$ & 17.61441 & 21.20816 \\
\hline INTSIM & $\mathrm{r} \leq 2$ & $\begin{array}{c}5.495332 \\
(\mathrm{k}=4)\end{array}$ & $\begin{array}{c}9.904916 \\
(\mathrm{k}=4)\end{array}$ \\
\hline CCI_MEN & $\mathrm{r}=0$ & $42.12201 *$ & $47.04079 *$ \\
\hline DOLLLAR & $\mathrm{r} \leq 1$ & 15.46622 & 21.53780 \\
\hline INTSIM & $\mathrm{r} \leq 2$ & 3.110453 & 10.45515 \\
\hline & & $(\mathrm{k}=4)$ & $(\mathrm{k}=4)$ \\
\hline CCI_MEN & $\mathrm{r}=0$ & $39.66143^{*}$ & \\
\hline ISĒE100 & $\mathrm{r} \leq 1$ & 16.64905 & \\
\hline INTSIM & $\mathrm{r} \leq 2$ & 6.318626 & \\
\hline & & $(\mathrm{k}=2)$ & \\
\hline CCI_MEN & $\mathrm{r}=0$ & $57.48590 *$ & \\
\hline ISË100 & $\mathrm{r} \leq 1$ & 34.65324 & \\
\hline INTSIM & $\mathrm{r} \leq 2$ & 19.46998 & \\
\hline DOLLAR & $\mathrm{r} \leq 3$ & 7.502043 & \\
\hline & & $(\mathrm{k}=2)$ & \\
\hline CCI_MEN & $\mathrm{r}=0$ & $54.15347^{*}$ & \\
\hline ISĒE100 & $\mathrm{r} \leq 1$ & 31.34416 & \\
\hline INTSIM & $\mathrm{r} \leq 2$ & 18.63268 & \\
\hline BASKET & $r \leq 3$ & 7.409448 & \\
\hline & & $(\mathrm{k}=2)$ & \\
\hline
\end{tabular}

Notes: The 5\% critical values for the Trace test with 3 variables are $35.19275,20.26184,9.164546$ for the Constant case, and 42.91525, 25.87211, 12.51798 for the Trend case. The 5\% critical values for the Trace test are with 4 variables are 54.07904, 35.19275, 20.26184, 9.164546 for the Constant case, and $63.87610,42.91525,25.87211,12.51798$ for the Trend case. $(*)$ denotes significance at 5\% level. $\mathrm{k}$ shows the lag length used in the estimation of the cointegration equation. 
Table 4. Johansen-Juselius cointegration tests-WOMEN

\begin{tabular}{|c|c|c|c|}
\hline PERIOD: 08/01/2003 - 23/01/2008 & & Constant & Trend \\
\hline VARIABLES & Null & Trace & Trace \\
\hline CCI WOMEN & $\mathrm{r}=0$ & $42.18055^{*}$ & $59.16353 *$ \\
\hline INTSIM & $r \leq 1$ & 19.95789 & 19.27082 \\
\hline BASKET & $r \leq 2$ & $\begin{array}{c}8.267627 \\
(\mathrm{k}=4)\end{array}$ & $\begin{array}{c}7.268864 \\
(\mathrm{k}=2)\end{array}$ \\
\hline CCI WOMEN & $r=0$ & $36.75201 *$ & $63.57303 *$ \\
\hline INTSIM & $r \leq 1$ & 15.88778 & 19.06899 \\
\hline DOLLAR & $\mathrm{r} \leq 2$ & $\begin{array}{c}4.501858 \\
(\mathrm{k}=4)\end{array}$ & $\begin{array}{c}7.244298 \\
(\mathrm{k}=2)\end{array}$ \\
\hline CCI WOMEN & $\mathrm{r}=0$ & $38.34600 *$ & $45.02259 *$ \\
\hline ISE100 & $r \leq 1$ & 14.20158 & 16.12970 \\
\hline DOLLAR & $\mathrm{r} \leq 2$ & $\begin{array}{c}4.576222 \\
(\mathrm{k}=6)\end{array}$ & $\begin{array}{c}2.951213 \\
(\mathrm{k}=4)\end{array}$ \\
\hline PERIOD: 08/01/2003 - 23/01/2008 & & Constant & Trend \\
\hline VARIABLES & Null & Trace & Trace \\
\hline CCI WOMEN & $\mathrm{r}=0$ & $53.30167 *$ & $58.32170^{*}$ \\
\hline ISE100 & $r \leq 1$ & 17.46381 & 19.41004 \\
\hline INTSIM & $r \leq 2$ & $\begin{array}{c}8.148066 \\
(\mathrm{k}=2)\end{array}$ & $\begin{array}{c}7.871585 \\
(\mathrm{k}=2)\end{array}$ \\
\hline CCI-WOMEN & $\mathrm{r}=0$ & $70.86858 *$ & $75.07910^{*}$ \\
\hline ISE100 & $r \leq 1$ & 33.13444 & 34.13917 \\
\hline BASKET & $\mathrm{r} \leq 2$ & 19.08453 & 21.33875 \\
\hline INTSIM & $r \leq 3$ & $\begin{array}{c}7.500432 \\
(\mathrm{k}=2)\end{array}$ & $\begin{array}{c}9.542042 \\
(\mathrm{k}=2)\end{array}$ \\
\hline CCI-WOMEN & $r=0$ & & $81.77118^{*}$ \\
\hline ISE100 & $r \leq 1$ & & 37.05647 \\
\hline DOLLAR & $r \leq 2$ & & 23.13989 \\
\hline INTSIM & $\mathrm{r} \leq 3$ & & $\begin{array}{c}11.07141 \\
(\mathrm{k}=2)\end{array}$ \\
\hline
\end{tabular}

Notes: The 5\% critical values for the Trace test with 3 variables are $35.19275,20.26184,9.164546$ for the Constant case, and 42.91525, 25.87211, 12.51798 for the Trend case. The 5\% critical values for the Trace test are with 4 variables are 54.07904, 35.19275, 20.26184, 9.164546 for the Constant case, and $63.87610,42.91525,25.87211,12.51798$ for the Trend case. $(*)$ denotes significance at $5 \%$ level. $\mathrm{k}$ shows the lag length used in the estimation of the cointegration equation.

Table 5. Normalized cointegrating coefficients from Johansen-Juselius estimation-MEN

\begin{tabular}{ccccc}
\hline \multicolumn{2}{c|}{ PERIOD: $\mathbf{0 8} / \mathbf{0 1 / 2 0 0 3}-\mathbf{2 3 / 0 1 / 2 0 0 8}$} & \multicolumn{2}{c}{ NORMALIZED VARIABLE: CCI-MEN } \\
\hline ISE100 & BASKET & DOLLAR & INTSIM & TREND \\
\hline & $-7.032780^{*}$ & $1.400414^{*}$ & \\
& $(2.37967)$ & $(0.49862)$ & \\
\hline & $-2.559867^{*}$ & $1.234282^{*}$ & $0.001449^{*}$ \\
& $(1.18347)$ & $(0.34004)$ & $(0.00049)$ \\
\hline
\end{tabular}


End of Table 4

\begin{tabular}{|c|c|c|c|c|}
\hline & & $\begin{array}{c}-4.674550 * \\
(1.69339)\end{array}$ & $\begin{array}{l}1.392227^{*} \\
(0.46010)\end{array}$ & \\
\hline & & $\begin{array}{c}-1.895658 \\
(1.06949)\end{array}$ & $\begin{array}{l}1.181490 * \\
(0.34026)\end{array}$ & $\begin{array}{l}0.001164^{*} \\
(0.00049)\end{array}$ \\
\hline $\begin{array}{l}0.642361 \\
(0.19656)\end{array}$ & & & $\begin{array}{l}1.432490^{*} \\
(0.36391)\end{array}$ & \\
\hline $\begin{array}{c}0.705719^{*} \\
(0.19721)\end{array}$ & & $\begin{array}{l}0.304797 \\
(0.96956)\end{array}$ & $\begin{array}{l}1.450265^{*} \\
(0.38426)\end{array}$ & \\
\hline $\begin{array}{c}0.608469 * \\
(0.21479)\end{array}$ & $\begin{array}{c}-0.558120^{*} \\
(1.15171)\end{array}$ & & $\begin{array}{l}1.404319 * \\
(0.41977)\end{array}$ & \\
\hline
\end{tabular}

Notes: The values in brackets under the coefficient estimates are the standard errors. $\left(^{*}\right)$ denotes significance at $5 \%$ level.

Table 6. Normalized cointegrating coefficients from Johansen-Juselius estimation-WOMEN

\begin{tabular}{|c|c|c|c|c|}
\hline \multicolumn{2}{|c|}{ PERIOD: 08/01/2003 - 23/01/2008 } & \multicolumn{3}{|c|}{ NORMALIZED VARIABLE: CCI-WOMEN } \\
\hline ISE100 & BASKET & DOLLAR & INTSIM & TREND \\
\hline & $\begin{array}{c}-10.56117^{*} \\
(4.07263)\end{array}$ & & $\begin{array}{l}3.204079 * \\
(0.85964)\end{array}$ & \\
\hline & $\begin{array}{l}1.212625^{*} \\
(0.58782)\end{array}$ & & $\begin{array}{l}1.098703 * \\
(0.17351)\end{array}$ & $\begin{array}{c}0.001808^{*} \\
(0.00025)\end{array}$ \\
\hline & & $\begin{array}{c}-4.236252 \\
(2.30723)\end{array}$ & $\begin{array}{c}2.232325^{*} \\
(0.63152)\end{array}$ & \\
\hline & & $\begin{array}{l}1.697506^{*} \\
(0.47840)\end{array}$ & $\begin{array}{c}0.996630 * \\
(0.15635)\end{array}$ & $\begin{array}{c}0.002064 * \\
(0.00023)\end{array}$ \\
\hline $\begin{array}{c}-0.870516^{*} \\
(0.29727)\end{array}$ & & $\begin{array}{c}3.055017^{*} \\
(0.60973)\end{array}$ & & $\begin{array}{c}0.003924 * \\
(0.00084)\end{array}$ \\
\hline $\begin{array}{c}0.343699^{*} \\
(0.13123)\end{array}$ & & $\begin{array}{l}1.340928 \\
(0.96263)\end{array}$ & & \\
\hline $\begin{array}{c}0.789739^{*} \\
(0.13053)\end{array}$ & & & $\begin{array}{l}1.689895^{*} \\
(0.24190)\end{array}$ & \\
\hline $\begin{array}{c}-0.142649 \\
(0.42929)\end{array}$ & & & $\begin{array}{l}1.265871^{*} \\
(0.28812)\end{array}$ & $\begin{array}{c}0.002216^{*} \\
(0.00100)\end{array}$ \\
\hline $\begin{array}{c}0.789959 * \\
(0.11693)\end{array}$ & $\begin{array}{l}1.197151 \\
(0.62623)\end{array}$ & & $\begin{array}{c}1.525828 * \\
(0.22862)\end{array}$ & \\
\hline $\begin{array}{c}-0.016744 \\
(0.38542)\end{array}$ & $\begin{array}{l}1.116621 \\
(0.60078)\end{array}$ & & $\begin{array}{l}1.190450^{*} \\
(0.26259)\end{array}$ & $\begin{array}{c}0.001945^{*} \\
(0.00090)\end{array}$ \\
\hline $\begin{array}{c}-0.094918 \\
(0.33967)\end{array}$ & & $\begin{array}{l}1.593921^{*} \\
(0.49020)\end{array}$ & $\begin{array}{l}1.011497 * \\
(0.24315)\end{array}$ & $\begin{array}{l}0.002311^{*} \\
(0.00079)\end{array}$ \\
\hline
\end{tabular}

See Notes of Table 5 in Appendix. 


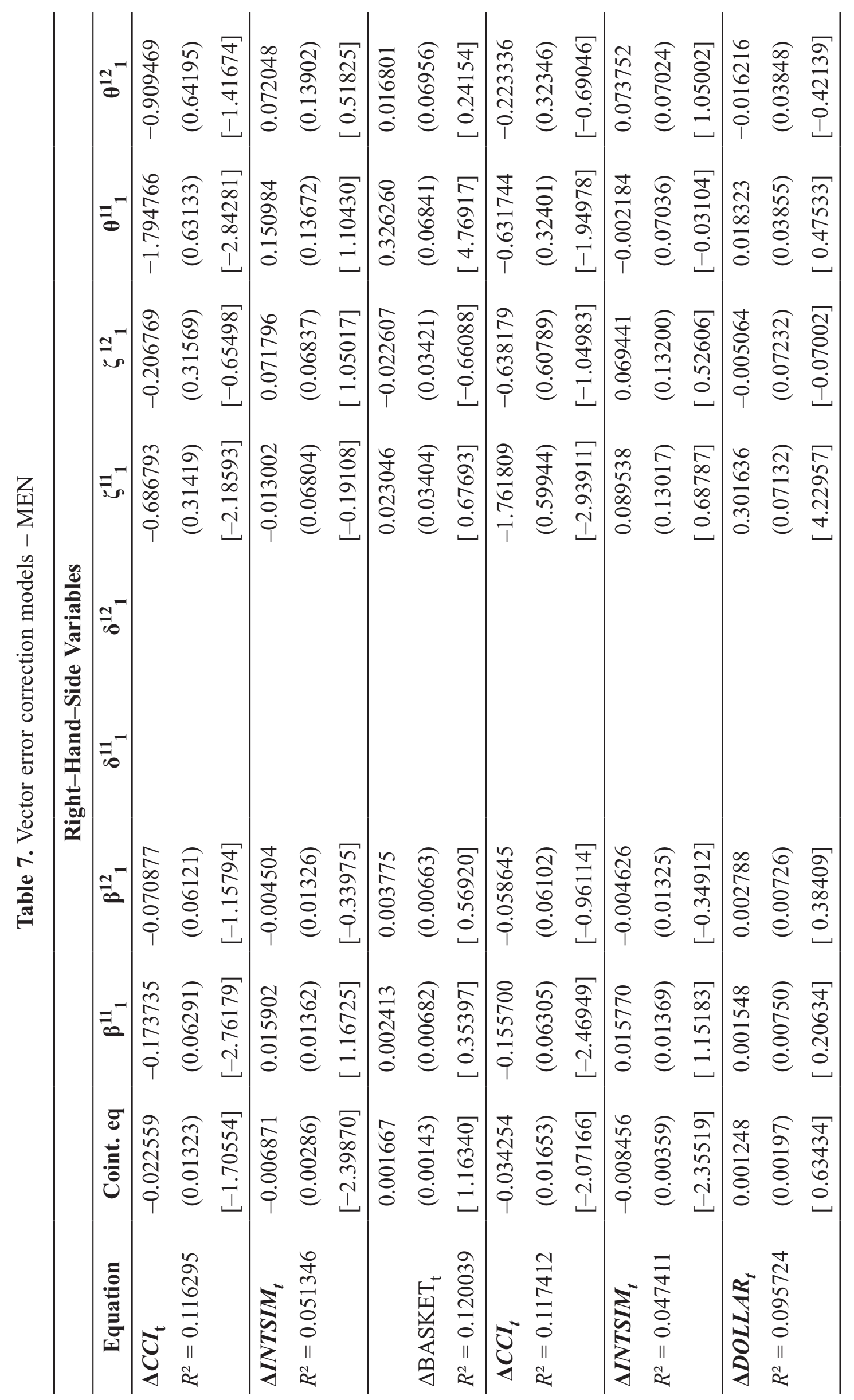




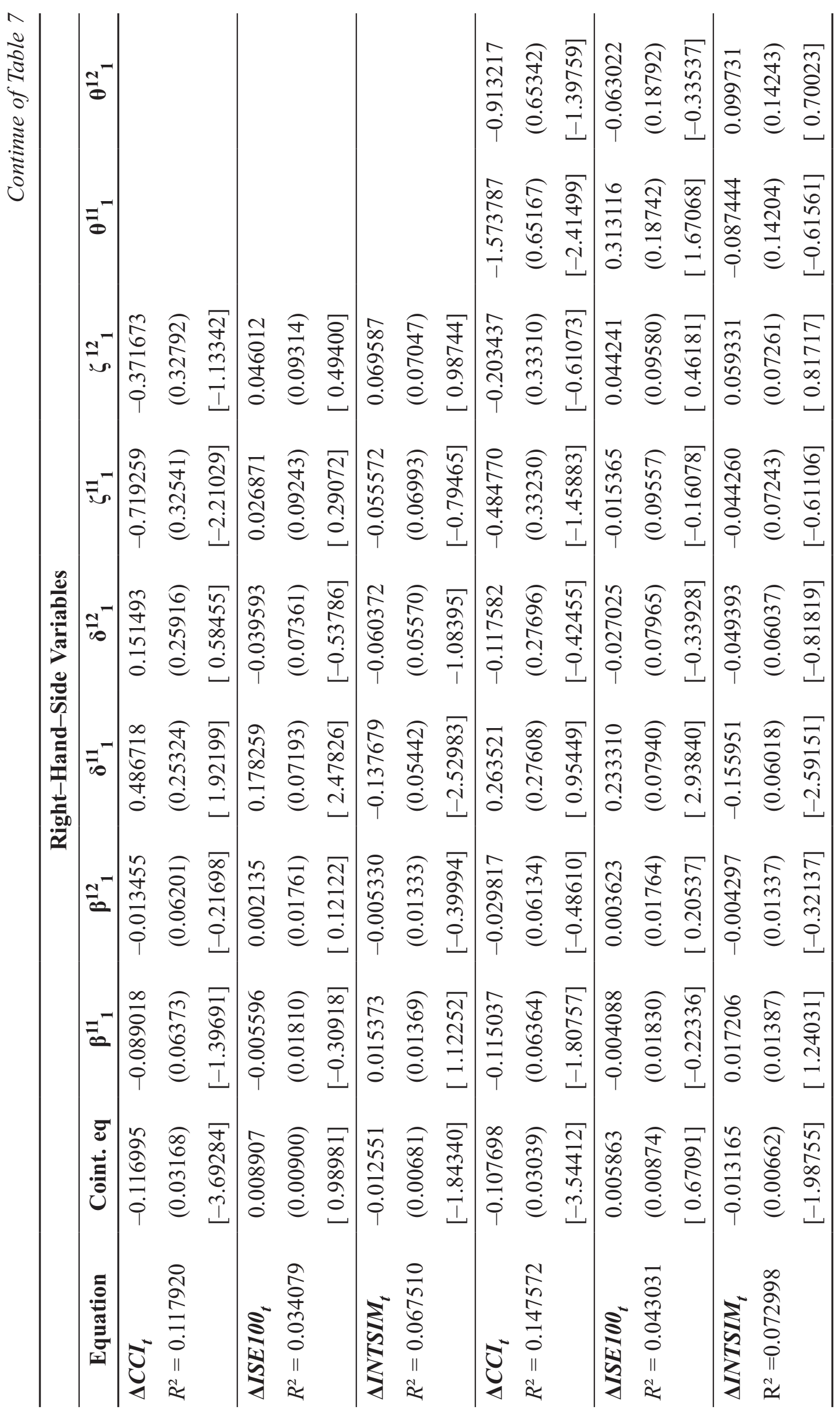




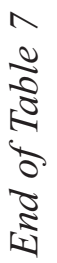

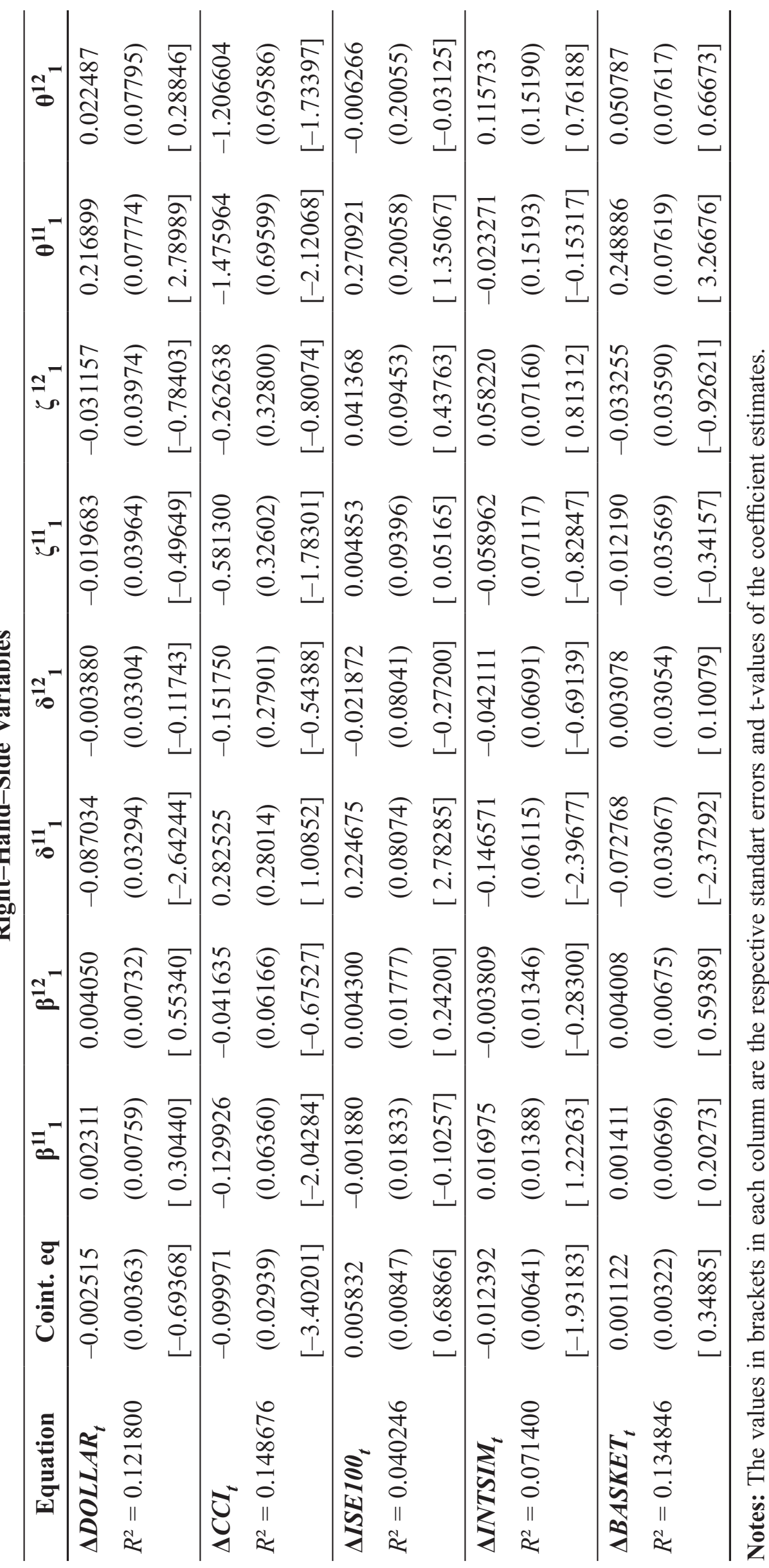




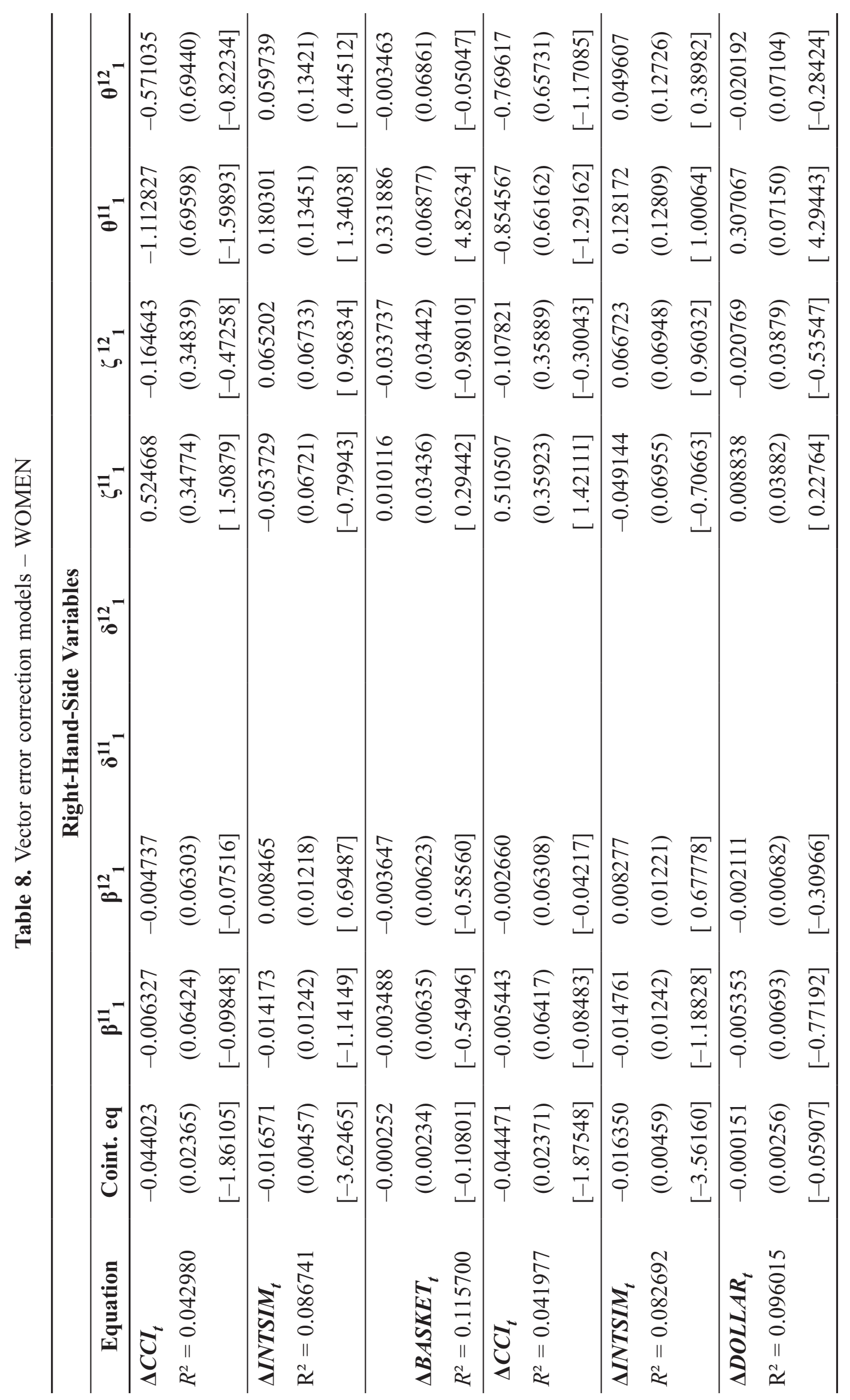




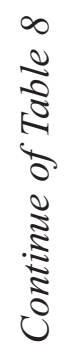
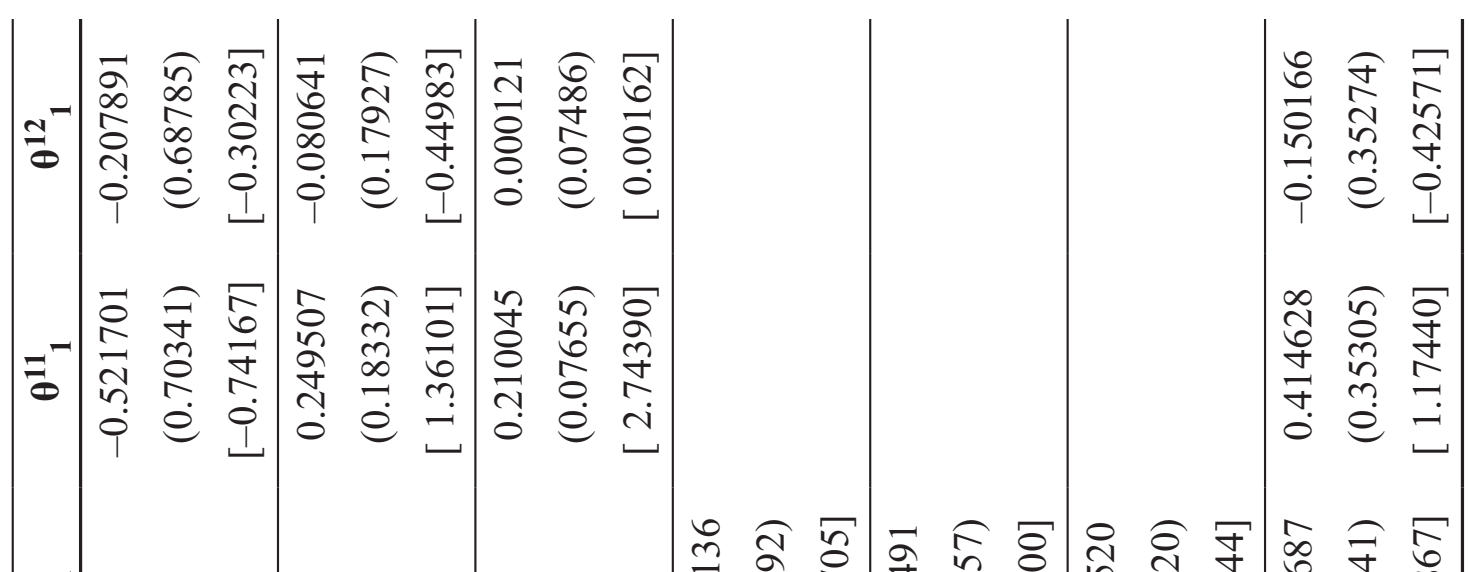

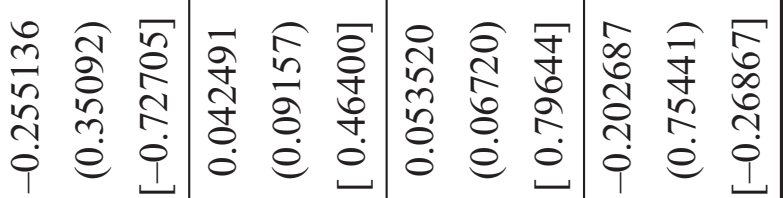

ב⿱⺈

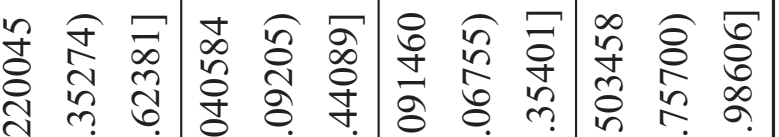

$=$

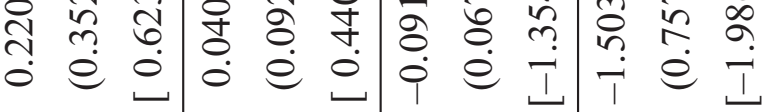

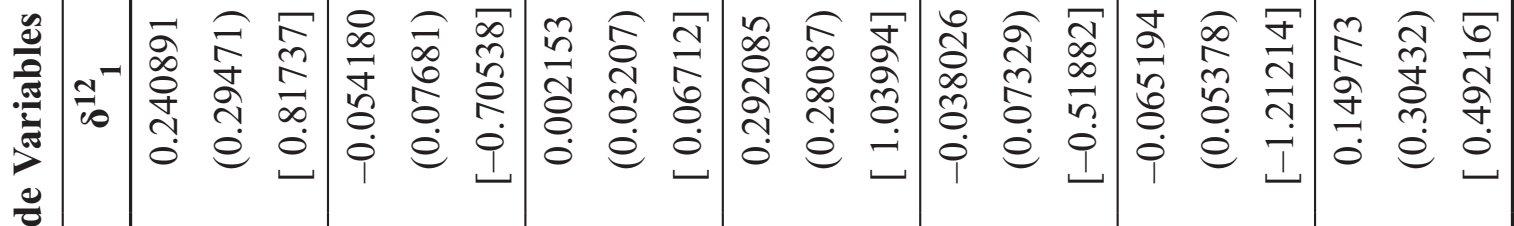

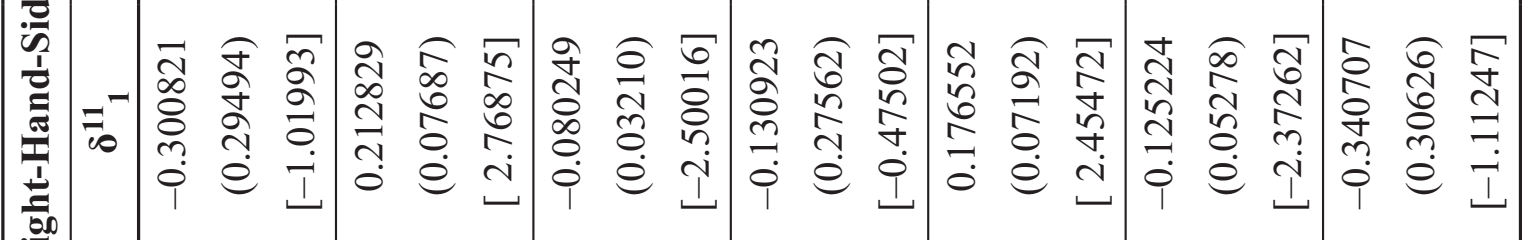
ㄸ

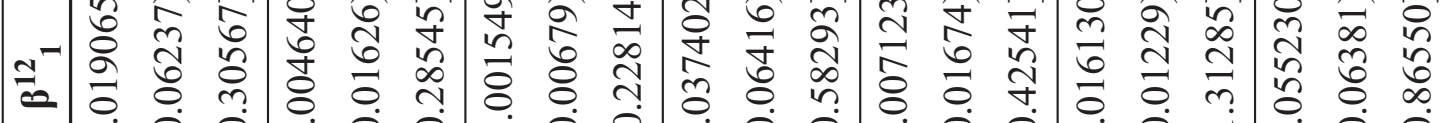

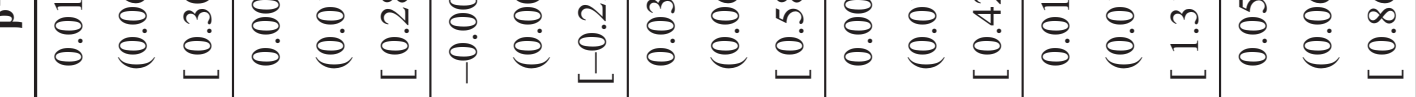

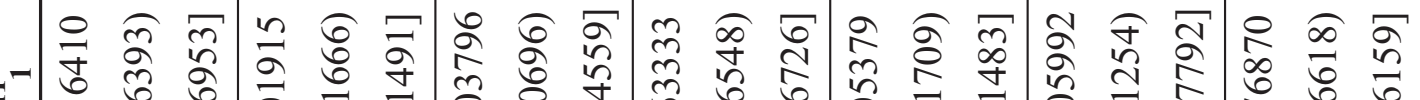

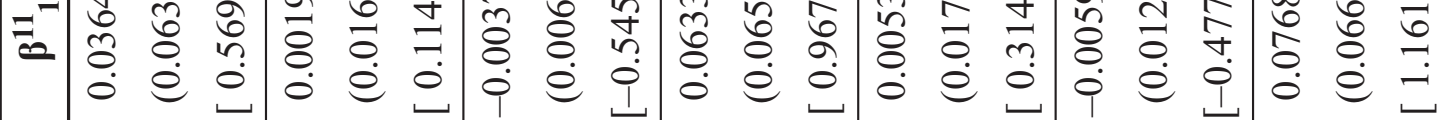

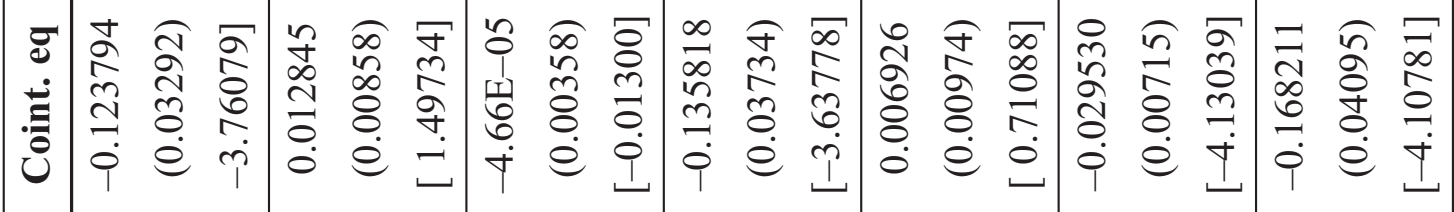

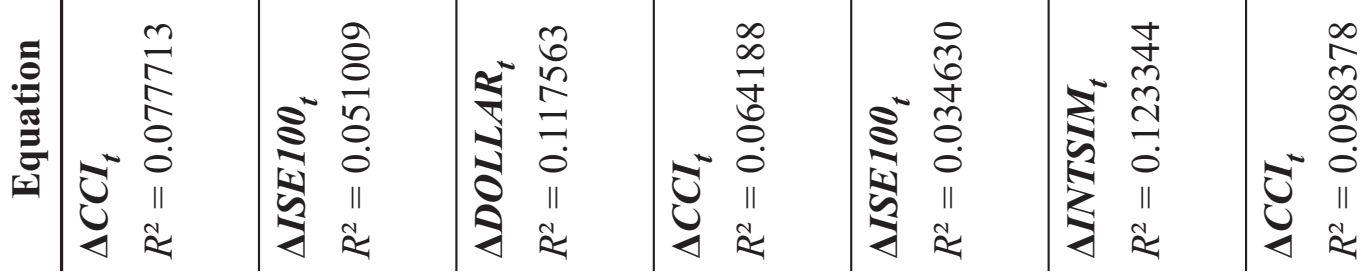




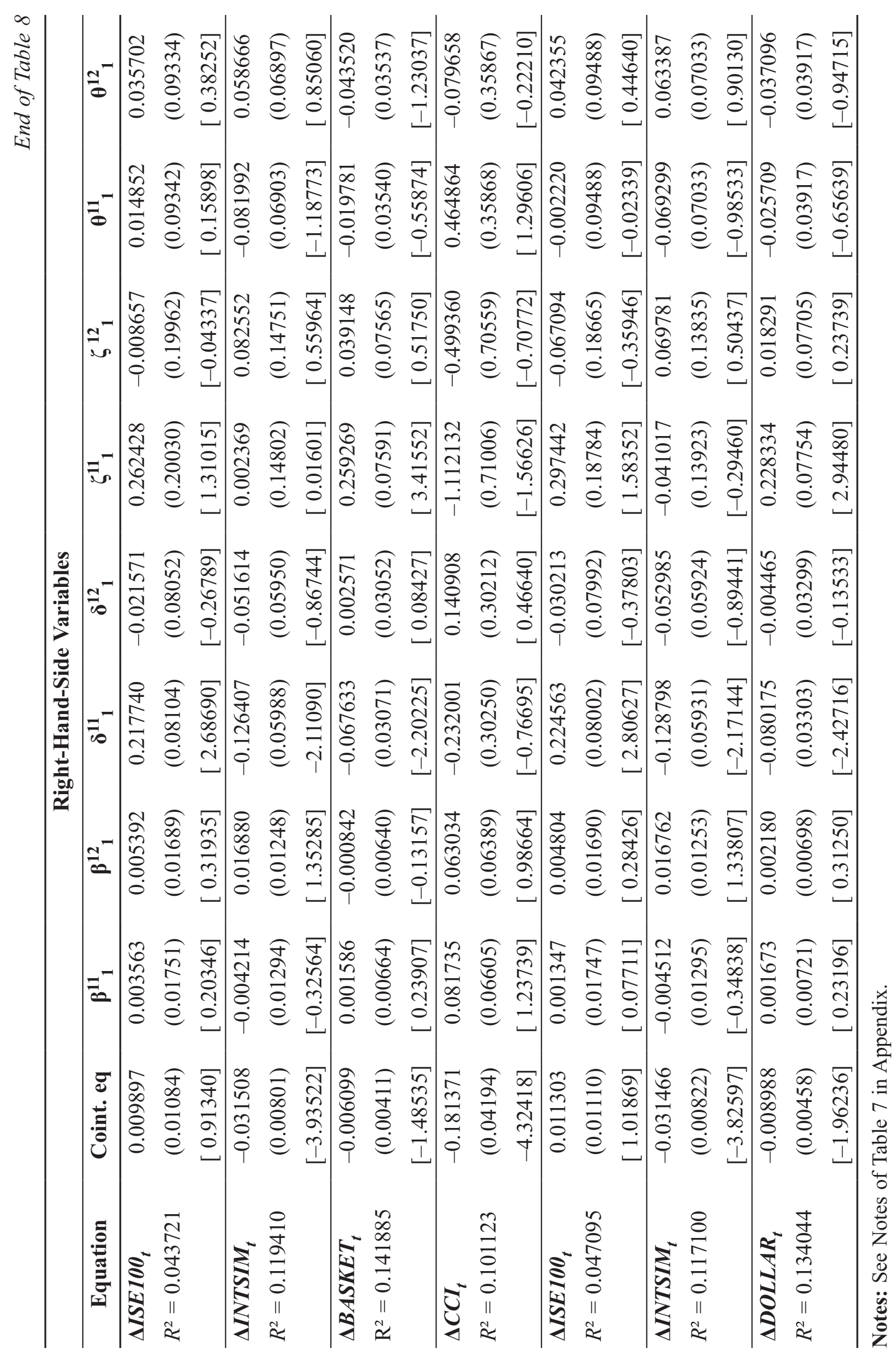

